\title{
The Impact of the 2008 Crisis on Total Insurers' Investment Portfolio in Europe: Dynamic Panel Approach
}

\author{
Elif Guneren Genc ${ }^{1} \&$ Ozlem Deniz Basar ${ }^{2}$ \\ ${ }^{1}$ Department of International Trade, Istanbul Commerce University, Istanbul, Turkey \\ ${ }^{2}$ Department of Statistics, Istanbul Commerce University, Istanbul, Turkey \\ Correspondence: Elif Guneren Genc, Ph.D., Department of International Trade, Istanbul Commerce University, \\ Istanbul, Turkey. E-mail: elifg@ticaret.edu.tr
}

Received: March 3, 2015

Accepted: March 11, 2015

Online Published: March 13, 2015

doi:10.5430/rwe.v6n1p208

URL: http://dx.doi.org/10.5430/rwe.v6n1p208

\begin{abstract}
Economic and financial crises change several balances in countries and affect many different sectors. In 2008, the economic and financial crisis occurred in the west influenced the insurance sector more than the banking sector in European countries. Investment portfolio of insurance companies might be affected by many variables. It is though that the crisis does not direct impacts but it affects these variables and causes changes in insurers' investment portfolio. In this study, models were formed in order to measure the impacts of the crisis on investment portfolio of insurance companies and results were compared. It was found out that the crisis in 2008 had impacts on total investment portfolio of European insurance companies and work and workplace premium were identified as the most effective variable in terms of increase in investment portfolio of companies.
\end{abstract}

Keywords: insurance, crisis, investment portfolio, dynamic panel, European countries

\section{Introduction}

Nowadays the insurance sector is getting more and more important in financial markets. This sector requires a dynamic structure as well as a financial source in order to adapt changing market conditions and to continue its development (Yücememiş et al., 2011). Insurance companies, which manage their financial portfolio to receive revenue, seek new sources to make more profits than their investment activities (Kuzmina and Voronova, 2011). Companies in the insurance sector acquire these financial sources in many different ways. These sources are declared as funds which can be used in time between premium and payments of the insured and claim payment with some limitations. The funds that were created through the insurance system might be potentially used to contribute a country's economic development (Ünal, 1994).

Insurance companies apply several different sources in order to extend their investment portfolio. Premium and claim payments can be considered as the factors that directly affect investment portfolio of companies. In addition, population of the companies' origin countries, as it demonstrates the largeness of the market, can be considered as a factor.

Insurance companies can be influenced by several economic factors while extending their investment portfolio. Among these factors, global economic crises are considered as the potentially most effective factor. As recent history indicated, economic crisis in 2008 negatively affected many sectors including the insurance sector. Kočović et al. (2011) stated that the global crisis did not directly affected investment portfolio of insurance companies but it led companies to change their preferences for their investment funds. Impavido and Tower (2009) identified that the global crisis in 2008 caused them to follow more conservative investment policies; therefore the impacts of the crisis were minimum. Particularly for non-life claims, these effects were kept in minimum. Liedtke and Schanz (2010) urged that the 2008 crisis had lesser impacts on the insurance sector in comparison to the banking sector. They gave the most significant reason for this is that the impacts of the crisis on liquidity risks of insurance companies occurred differently than other financial institutions' liquidity risks. Schich (2009) however argued that the crisis had considerable effects on insurance companies, particularly on changes of their investment portfolio and financial market values. 
While the impacts of the global crisis in 2008 on investment portfolio of insurance companies in European companies, it is possible to extract different results. It is safe to say that insurance companies in Latvia, Bulgaria, Malta, Croatia, Portugal, Austria, Spain, Denmark and Germany used the crisis as an opportunity (investment portfolio values in Latvia, Bulgaria, Malta and Croatia are lower than other countries, so these are not shown on the graph). The companies in these countries, both during and after the crisis, increased their values concerning their investment portfolio.

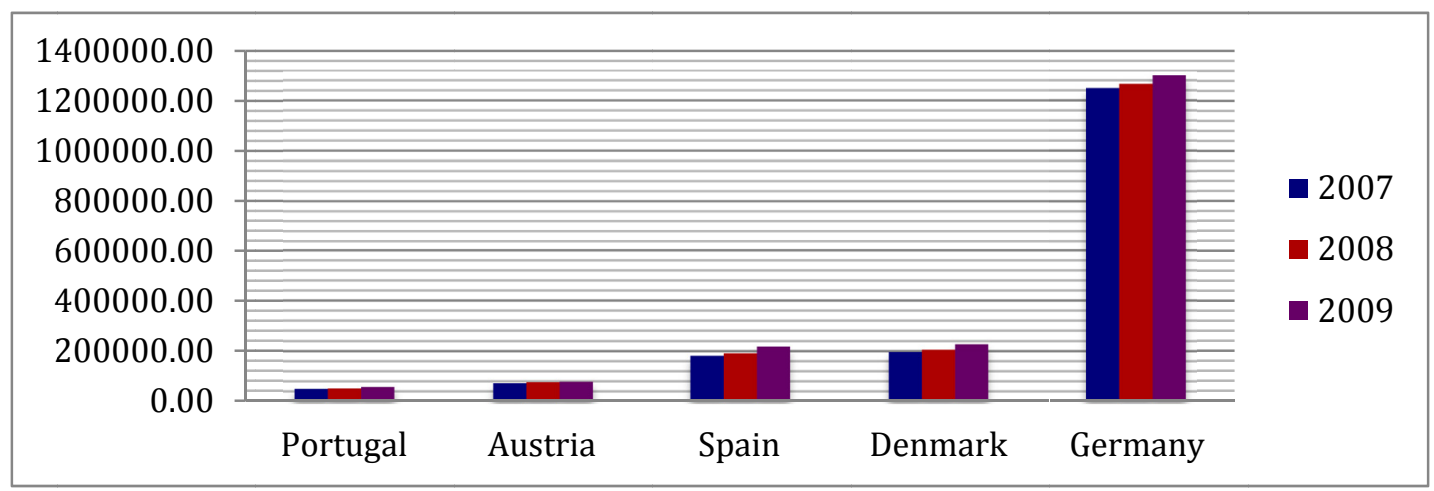

Figure 1. Countries with continuous increase trend in investment portfolio values

European countries such as Estonia, Cyprus, Slovakia, Slovenia, Hungary, Czech Republic and Greece did not experience a stable growth or recession during the economic crisis. Portfolio values of insurance countries in some of these counties diminished during the crisis but next year they experienced an increase in these values. Even some countries reached higher levels than the years before the crisis.

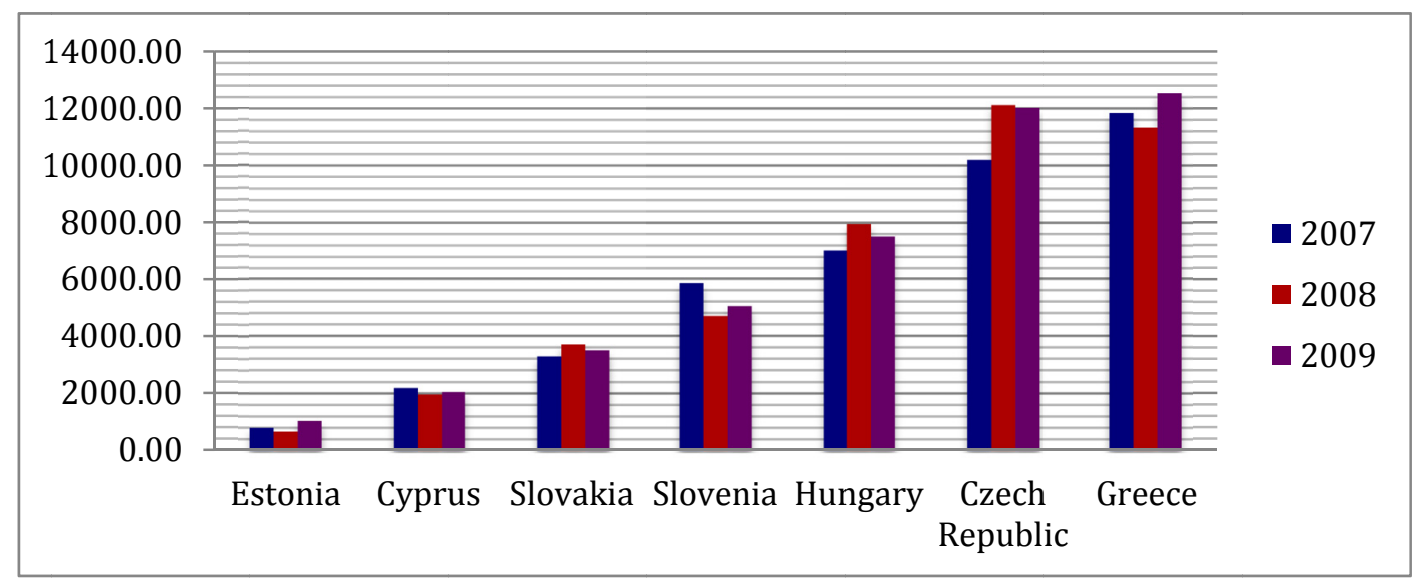

Figure 2. Countries lacking continuous increase trend in investment portfolio values

In countries like Iceland, Romania, Turkey, Norway and United Kingdom, the view that was created by the crisis is rather darker (investment portfolio values in Iceland, Romania and Turkey are much lower than other countries. Because of that, only Turkey is shown on the graph in order to understand the country's position among others). In these countries, total investment portfolio values of insurance companies decreased during the crisis and this tendency to decrease continued in the following years. Therefore it is not possible to claim the crisis had similar impacts on the insurance sector in Europe. 


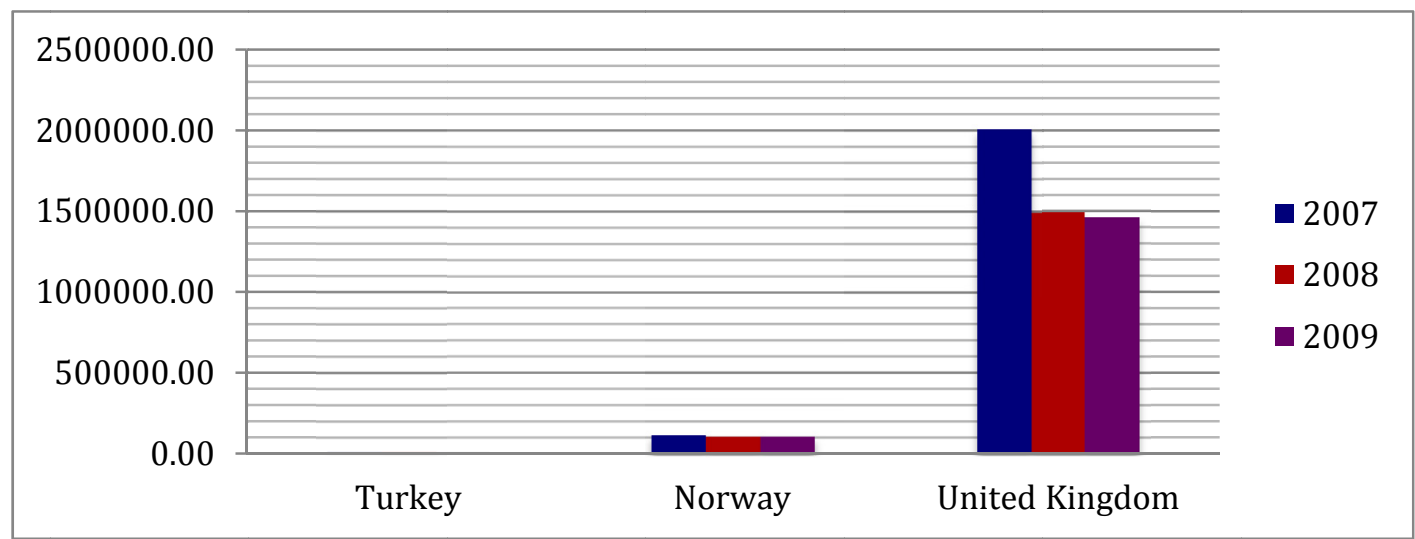

Figure 3. Countries with continuous decrease trend in investment portfolio values

This study analysed and modelled variables that might have impacts on investment portfolio in two different cases separately. In the first case, with the assumption that the crisis had no effects, possible variables that are considered to influence investment portfolio of insurance companies were examined. In the second case, the same variables, with regard to the impacts of the global economic crisis in 2008, were used to form models.

\section{Methodology}

Dynamic panel data models can be examined as two groups: autoregressive panel data models and distributed lag panel data models. In autoregressive panel data models, lag values of dependent variables are included as independent variables whereas in distributed lag panel data models, lag values of independent variables are considered as independent variables. Dynamic panel data models are generally analysed as autoregressive panel data models.

$$
Y_{i t}=\alpha_{i}+\gamma Y_{i, t-1}+\beta X_{i t}^{\prime}+v_{i t} \quad \mathrm{i}=1,2, \ldots, \mathrm{N} \text { (individuals), } \quad \mathrm{t}=1,2, \ldots, \mathrm{T} \text { (time) }
$$

Here, $v_{i t}=\mu_{i}+u_{i t}$

In this model, lag values of the dependent variable are on sides of independent variables. In this model $X_{i t}$ are regressors $\left(X_{i t}\right.$ will be strictly exogenous $\left(X_{i t}\right.$ are uncorrelated with $\left.\left.v_{i t} \forall i, t\right)\right), \mu_{i}$ is fixed (by construction, $Y_{i, t-1}$ is correlated with $\mu_{i}$ ) individual effects, and $v_{i t}$ has zero mean, constant variance, and is uncorrelated across time and indiviauals. In dynamic models, estimators based upon Ordinary Least Squares (OLS) and Generalized Least Squares (GLM) are biased and inconsistent (Bond, 2002). This is because in dynamic models due to past shocks and $Y_{i, t-1}$ is correlated with $u_{i t-1} . Y_{i t}$ is a function of $\mu_{i}$ and it is also correlated with error term consisting of $\mu_{i}$.

An alternative transformation to remove individual effects $\mu_{i}$ is called "the first-difference" information:

$$
\Delta y_{i t}=\gamma \Delta y_{i, t-1}+\beta \Delta x_{i t}^{\prime}+\Delta v_{i t}
$$

The first difference is dropped from the $\mu_{i}$ model with its transformation. As the lag dependent variable is internal and model's independent variable $\left(\Delta Y_{i, t-1}\right)$ and error term is not orthogonal, biased estimators are obtained. In situations where there is a relationship between independent variables and error term, instrumental variables regression is used to make estimators consistent. However, the effectiveness of the estimators varies according to the instrumental variable method used. In dynamic models, the instrumental variable method was first suggested by Anderson and Hsiao (1982). Anderson and Hsiao (1982) suggested excluding the first differences model and $\mu_{i}$ unit effects from the model and using $\left(\Delta Y_{i, t-1}\right)$ instead of $\left(\Delta Y_{i, t-2}\right)$ or $\left(Y_{i, t-2}\right)$. Therefore, consistent but ineffective estimators were acquired. Arrelano and Bond (1991) used the moments consisting of all possible lag values of the dependent variable and estimated a model with more instrumental variables (Zeren and Ergun, 2010, p.77). They obtained these estimations through a single-step and two-step Generalized Method of Moments (GMM) methods. In all instrumental variables regression models, GMM estimators have non-biased and smaller variance (Garza et al., 2011).

Arellano and Bover (1995) used the "orthogonal variation" method and suggested effective instrumental variable method. Blundell and Bond (1998) suggested an alternative method. Blundell and Bond focused on the orthogonality 
condition $\mathrm{T}=3,(\mathrm{~N}>\mathrm{T})$ and $E=\left(Y_{i l} \Delta u_{i 3}\right)=0$ and emphasized the importance of extra moment criterion in order to acquire effective estimator of the dynamic panel data model.

Windmeijer (2005) considered that standard errors produce biased results under heteroscedasticity, stated the necessity for using a modified instrumental variable and suggested two-step GMM model. As the first differences method remains weak and $\mathrm{T}$ is small, this study employed the Arellano and Bover/Blundell method and "Bond System Generalized Method of Moments".

\section{Implementation}

The financial and economic crisis, which began in 2008 in the west, was the worst crisis in the last 70 years. It is much more severe than Asian crisis in the 1990s and the 2001 crisis that occurred after the 7/11 events. The aim of this study to investigate the impacts of the crisis in 2008 on total investment portfolio of insurance companies in European countries between 2007 and 2012 and to analyse variable that have affected total investment portfolio in this above-mentioned period.

The insurance market is mostly under the influence of past experiences and old habits. Therefore, it is very important to consider lag values as explanatory factors in examining total investment portfolio of insurance companies (Arena, 2008). In this study, dynamic panel data estimators were used in order to investigate the impacts of the former period on total investment portfolio of insurance companies. Thereby, the effects of dynamic structure of portfolio on variables can also be empirically observed. We used two-step difference GMM estimators with the Windmeijer correction.

In this study, for the insurance companies located in 30 European countries, the changes in the variable total insurers' investment portfolio in Europe (TIIPE) were explained through the variables the number of Insurance Companies (NIC), total direct life premium income (TLPI), life benefits paid (LBP), nonlife claims paid (NLCP), motor gross written premiums (MGWP), motor claims paid (MCP), European property gross written premiums (EPGWP), gross domestic products (GDP), population (POP) and the Dummy variable (D1), which was formed to include the impacts of the crisis. The data used in this study were acquired from the official website of Insurance Europe (European (re)insurance federation). The list of included countries was given on Appendix-1.

Descriptive statistics concerning these variables are shown on Table 1. The average value of investment portfolio for 30 European countries was found 242892.40 and standard deviation was found 456818.40 . The average number of insurance companies, for the 30 countries that were analysed, was calculated 174.4. Among these 30 countries, the least number of insurance companies is in Iceland (9) and the most in United Kingdom (1314).

Table 1. Descriptive statistics

\begin{tabular}{ccccc} 
Variables & Mean & Std.Dev. & Min. & Max. \\
\hline \hline$T I I P E$ & 242892,4 & 456818,4 & 304,8 & 2007124 \\
$N I C$ & 174,4 & 228,1 & 9 & 1314 \\
$T L P I$ & 21817,7 & 43185,7 & 18,9 & 295249,9 \\
$L B P$ & 19614,6 & 41814,7 & 4,2 & 248639,5 \\
$N L C B$ & 9819,4 & 16255,8 & 39,8 & 67535 \\
$M G W P$ & 4249,1 & 6316,3 & 50,1 & 21989 \\
$M C P$ & 3266,2 & 5280,3 & 26,4 & 20444 \\
$E P G W P$ & 2779,8 & 4448,9 & 20 & 17837,2 \\
$G D P$ & 454291 & 640183 & 5557,4 & 2609900 \\
$P O P$ & $1.82 \mathrm{E}+07$ & $2.40 \mathrm{E}+07$ & 31763 & $8.23 \mathrm{E}+07$ \\
\hline
\end{tabular}

The study analysed two situations. In the first situation, the impacts of the global crisis in 2008 were ignored and a model (Model 1), which demonstrated the significance of concerning variables in explaining the total insurers' investment portfolio in Europe variable, was formed. In the second situation, the impacts of the global crisis in 2008 were included in the model (Model 2) and significance of variables that explained the dependent variable was re-examined. The results concerning these models are summarized on Table 2. 
Table 2. The results concerning the model

\begin{tabular}{|c|c|c|}
\hline & Model 1 & Model 2 \\
\hline \multirow[t]{2}{*}{ Constant } & $-61843.22 * * *$ & $-55788.93^{* *}$ \\
\hline & 19679.98 & 22408.34 \\
\hline \multirow[t]{2}{*}{ TIIPE(-1) } & $-0.70561 * * *$ & $-0.66443 * * *$ \\
\hline & 0.02811 & 0.025802 \\
\hline \multirow[t]{2}{*}{ NIC } & $-308.4151 * * *$ & $-306.2636^{* * *}$ \\
\hline & 25.58657 & 27.51779 \\
\hline \multirow[t]{2}{*}{ TLPI } & $-0.58413 * * *$ & $1.40074 * * *$ \\
\hline & 0.28246 & 0.47187 \\
\hline \multirow[t]{2}{*}{ EPGWP } & $191.0295 * * *$ & $179.9473 * * *$ \\
\hline & 5.18231 & 4.62166 \\
\hline \multirow[t]{2}{*}{ LBP } & $1.14219 * * *$ & $1.08981^{* * *}$ \\
\hline & 0.27569 & 0.28596 \\
\hline \multirow[t]{2}{*}{ MCP } & $-19.58834 * * *$ & $-10.32276^{*}$ \\
\hline & 4.24747 & 5.43184 \\
\hline \multirow[t]{2}{*}{ POP } & $0.00062 * * *$ & $0.0004813^{* *}$ \\
\hline & 0.00018 & 0.000226 \\
\hline \multirow[t]{2}{*}{ D1 } & & $-13413.53 * * *$ \\
\hline & & 2783.622 \\
\hline $\mathrm{N}$ and \# of groups & $150-30$ & $150-30$ \\
\hline Wald Statistics (df) & $26722.04(7)$ & $12233.79(8)$ \\
\hline Number of Instrument & 21 & 22 \\
\hline $\begin{array}{l}\text { Arellano-Bond test for zero } \\
\text { autocorrelation in }\end{array}$ & $\operatorname{AR}(1)=0.06649$ & $\mathrm{AR}(1)=0.08742$ \\
\hline first-differenced error & $\operatorname{AR}(2)=0.38934$ & $\mathrm{AR}(2)=0.994$ \\
\hline
\end{tabular}

According to the research findings, variables that were found significant can be interpreted as follows;

It was found out that the NIC (number of insurance companies) variable had diminishing effect on the total insurers' investment portfolio in Europe variable in both Model 1 and Model 2. This situation can be interpreted that the increase in number of companies in a particular country leads to share of the market with more companies; consequently their shares in the extended market decrease. It was observed that TLPI (total direct life premium income) had negative and little effect on the TIIPE variable in Model 1 whereas it had positive effect in Model 2. It was found out that the EPGWP (European property gross written premiums) variable was the most effective one on the TIIPE variable. Nevertheless, it can be said that this impact is lesser than before the 2008 global crisis. The impact of the $L B P$ (life benefits paid) variable had on the TIIPE variable was found positive. However considering the effects of the crisis, it can be said that this impact decreased a bit. The impact of the MCP (motor claims paid) variable on the dependent variable was found decreasing. Payments of insurance companies result in recession of their investment portfolio. However, as this model included the impacts of the crisis, the amount of this decrease was found even smaller. The effects of the POP (population) variable on the TIIPE variable was identified very small, almost zero but significant. As the population grows, the number of the insured is expected to grow. The expected increase in the model, where the impacts of the crisis were examined, was more than the other model where the impacts of the crisis were excluded. The D1 (Dummy indicating the impacts of the crisis) variable was added to the Model 1 in order to include the impacts of the global economic crisis in 2008. This variable was found negative and significant. Thereby, this shows that the crisis had diminishing effects on the total insurers' investment portfolio. In this context, it is possible to claim that the 2008 crisis influenced the insurance sector. Nevertheless, the lag of the total insurers' investment portfolio in Europe (TIIPE) variable negatively affected the TIIPE variable. This situation can be interpreted that the crisis spread and consequently total insurers' investment portfolio was negatively affected. 
Moreover, decrease of the demand in the sector can only be balanced in the medium term.

In the model, the $\mathrm{AR}(1)$ and $\mathrm{AR}(2)$ tests were applied in order to determine whether there was autocorrelation. In dynamic panel data models, first degree autocorrelation is frequently encountered and it is considered natural due to the own structure of the model. In the model, no finding was acquired concerning second degree autocorrelation. The absence of second degree autocorrelation shows that GMM estimates were consistent.

\section{Conclusion}

Economic and financial crisis affect the insurance sector as they have impacts on all other sectors. It can be said that the insurance sector is seriously vulnerable during crisis periods as the products of the insurance sectors gives guarantee to the risks of the finance, banking and real estate sectors in several fields. In addition, this is because the insurance sector can be considered as additional and escapable costs in such times. Nonetheless, insurance companies face new types of risks due to their increasing cross-border transactions. As economic crisis spread other countries, there are many factors affecting investment portfolio of insurance companies. In the light of these research findings, the aim of this study is to examine the impacts of the 2008 crisis on total investment portfolio of insurance companies in European counties and to analyse variables affecting it.

The analysis indicates that the following variables have influences total investment portfolio of insurance companies: number of insurance companies, total direct life premium income, life benefits paid, nonlife claims paid, motor gross written premiums, motor claims paid, European property gross written premiums, gross domestic products, population. It was identified that companies should reconsider their positions with regard to these variables and control values concerning them. In addition due to direct and indirect impacts of the crisis, insurance companies experience considerable losses in their premium revenue during crisis periods. It was also found out that the increase in number of insurance companies in these countries caused a decrease in portfolio of companies in an extremely competitive market.

Finally, it was identified that the 2008 crisis had impacts on total investment portfolio of insurance companies in Europe. It was also found out that the most increasing effect on investment portfolio of insurance companies was caused by European property gross written premiums.

\section{References}

Anderson, T.W., \& Hsiao, C. (1982). Formulation and Estimation for Dynamic Models Using Panel Data. Journal of Econometrics, 18, 47-82. http://dx.doi.org/10.1016/0304-4076(82)90095-1

Arellano, M., \& Bover, O. (1995). Another look at the instrumental varible estimation of error-components models. Journal of Econometrics, 68, 29-51. http://dx.doi.org/10.1016/0304-4076(94)01642-D

Arena, M. (2008). Does Insurance Market Activity Promote Economic Growth? A Cross-Country Study for Industrialized and Developing Countries. The Journal of Risk and Insurance, 75(4), 921-946.

Blundell, R., \& Bond, S. (1998). Initial conditions and moment restrictions in dynamic panel data models. Journal of Econometrics, 87, 115-143. http://dx.doi.org/10.1016/S0304-4076(98)00009-8

Bond, S. (2002). Dynamic Panel Data Models: A Guide to Micro Data Methods and Practice. Working paper, The Institute for Fiscal Studies Department of Economics. UCL. CWP09/02. Retrieved from http://www.cemmap.ac.uk/wps/cwp0209.pdf

Garza, P.B., Bucheli, M., \& Munoz, T.G. (2011). Dynamic panel data: A useful technique in experiments. The Papers Series: 10/22. Retrieved from http://hdl.handle.net/10481/31576

Impavido, G., \& Tower, I. (2009). How the Financial Crisis Affects Pensions and Insurance and Why the Impacts Matter. IMF Working Paper, International Monetary Fund. July.

Kočović, J., Antić, T.R., \& Jovović, M. (2011, October-December). The Impact of the Global Financial Crisis on the Structure of Investment Portfolios of Insurance Companies. Economic Annals, LVI(191), 143-161.

Kuzmina, J., \& Voronova, I. (2011). Development of Investment Risk Management Models for Insurance Companies. Economics and Management, 16, 1147-1153.

Liedtke, P.M., \& Schanz, K.U. (2010). The Global Financial Crisis and the Insurance Industry Frequently Asked Questions. Research on Finance Issues in Insurance, SC9 Insurance and Finance.

Retrieved 14 February 2014, from www.insuranceeurope.eu 
Schich, S. (2009, October). Insurance Companies and The Financial Crisis. OECD Journal: Financial Market Trends, 2009(2).

Stata Logitudinal-Data/Panel-Data Reference Manual Release 11, A Stata Press Publication StataCorp LP College Station, Texas, Published by Stata Press, 2009.

Ünal, T. (1994). Sigorta Sektörünün Ekonomik İslevi ve Fon Yaratma Kapasitesi. İstanbul Ticaret Odası, İstanbul.

Windmeijer, F. (2005). A finite sample correction for the variance of linear efficient two-step GMM estimators. Journal of Econometrics, 126, 25-51. http://dx.doi.org/10.1016/j.jeconom.2004.02.005

Yücememiş, B.T., Akpınar, Ö., \& Okay, G. (2011). Türk Sigorta Sektöründe Yabancı Payının Sektöre Olası Etkileri: AB Perspektifinde Değerlendirilmesi. Avrupa Araştırmaları Dergisi, Cilt:19, Sayı:1, 53-75.

Zeren, F., \& Ergun S. (2010). The Determinants of Foreign Direct Investment Flows in EU: Dynamic Panel Data Analysis, Business and Economics Research Journal, 1(4), 67-83.

Appendix 1. The list of countries

\begin{tabular}{lll}
\hline Austria & Belgium & Bulgaria \\
\hline Switzerland & Cyprus & Czech Republic \\
\hline Germany & Denmark & Estonia \\
\hline Spain & Finland & France \\
\hline Greece & Croatia & Hungary \\
\hline Ireland & Iceland & Italy \\
\hline Latvia & Malta & Netherlands \\
\hline Norway & Poland & Portugal \\
\hline Romania & Sweden & Slovenia \\
\hline Slovakia & Turkey & United Kingdom \\
\hline
\end{tabular}

